\title{
Environmental Law that Affects the Green Behaviour of Undergraduates at Northeastern University
}

Sapphasit Kaewhao, Department of Environmental Science, Faculty of Science and Technology, Rajabhat Maha Sarakham University, Mahasarakham 44000, Thailand, Email: sapphasit1981@gmail.com

The objectives of this study were.to study environmental damage, natural resource damage, ecological damage, civil liability, criminal liability, administrative liability, and green behaviour levels and to study the independent variables comprising environmental damage, natural resource damage, ecological damage, civil liability, criminal liability, and administrative liability affecting the dependent variable of the green behaviour of undergraduates. The research instrument was the questionnaire, and it was used for data collection from 400 undergraduates. The inferential statistics that were used was the multiple regression analysis. Research results was revealed that the mean scores of environmental damages, natural resource damage, ecological damage, civil liability, criminal liability, administrative liability, and green behaviour levels were at high levels for all aspects. Moreover, it was found that the criminal liability had the most effect towards people's air quality maintenance behaviour at a rate of 23.6 percent and was statistically significant at the level of 0.01. It was followed by administrative liability with 17.00 percent, which was statistically significant at the level of 0.01 . This might indicate that the undergraduates realized to the important of criminal liability to enforces the people's air quality maintenance. Therefore, in order to control air quality effectively, the criminal liability is needed to use to accomplish the air quality control.

Key Words: Environmental Law / Green Behavior / Public Mind Inspiration / Undergraduates 
International Journal of Innovation, Creativity and Change. www.ijicc.net

Volume 15, Issue 2, 2021

\section{Introduction}

Environmental law is certain type of law that is principally issued for environmental conservation. The content includes the prevention and remedy of environmental degradation, especially, protecting humans and other creations of health. It is often interrelated with the common law, conventions, treaties, agreements, commitments, rules, regulations, and policies (Thienkamol, 2011e; Borvornsakulcharoen et al., 2015).

Several types of environmental law might define the environmental quality and condition to operate certain types of human activities, such as a specification for the quantity of pollution that can occur or a specification on the plan and mitigation required for certain activities. A governmental policy is a precautionary principle, which is based upon polluter pay principles. Moreover, the people's participation is also recognised and the environmental court is established (LSE, 2018).

Since the early nineteen-seventies, Thailand has enacted laws that are designed to protect the country environment and its plentiful natural resources. This has also been a time of important emphasis on the social and economic development of the country because of rapid economic growth. The environmental protection does not always work, nevertheless, enforcing environmental laws has now become a matter of urgency (Thienkamol, 2011e; LSE, 2018).

The issues of global warming and deforestation have recently been directed to the public's attention in Thailand. All legal aspects relating to land use and industrial activities, particularly public construction law, are crucial in environmental matters (Richardson, B.J. \& S. Wood [eds], 2006). The right to sue is also important in court organisations, which advocate that environmental issues are recognised as actual environmental protection. The Board of Investment (BOI) also issues new policies to reflect the growing awareness for environmental subjects, as well as encourages environmentally friendly investments.

Nowadays, in Thailand, environmental laws are complex because there are a large number of acts, rules, and regulations which need to be compiled and combined into a group of environmental law. Thus, the services of a good legal firm are required to handle these concerns.

Environmental issues remain in the forefront in Thailand because of the numerous problems of environmental litigation, as a byproduct of the pollution problems rising. Therefore, the number of court cases related to breaches in environmental law are rapidly increasing. Recently, a new Civil Court division was opened specifically to handle the cases linking environmental issues (Borvornsakulcharoen et al., 2015). This new division was required because of the large number 
International Journal of Innovation, Creativity and Change. www.ijicc.net

Volume 15, Issue 2, 2021

of cases brought forth by those affected by pollution from industrial operations, including air pollution, chemical pollution, hazardous waste pollution, and others. All environmental cases filed with the Civil Court will be tried by this new court. The court is designed to give all Thais recourse to the courts, without requiring the expense of a large amounting of funding.

Environmental laws cover a wide range of topics, including the air quality laws, which protect the air from pollution and may include measures to protect the air from elements such as ozone depletion; and water quality environmental laws, which may protect bodies of and sources of water from pollution. They may also determine who can use water and how to handle potential problems, such as treating wastewater and managing surface run off. Waste management municipal waste, hazardous substances, and nuclear waste all fall within the category of waste management (Thiengkamol, 2011e).

The term, 'natural resources damage', refers to whenever a spill or release of contaminants into the environment results in damage to the natural resources. The damages are sought from the party or parties who are legally responsible, in an effort to restore the harmed natural resources and compensate the public. The aims of a natural resources damages claim are the restoration, replacement or acquisition of the equal of the threatened resources, and remuneration for past and future lost services that the damaged resources would have provided, had they not been damaged by the release. The damages also comprise the cost of the damage assessment. The "natural resources' that may be the subject of the claim include, but are not limited to: land, water, groundwater, drinking water supplies, air, fish, wildlife, and the biosystem (Department of Environmental Conservation, 2019).

Thailand has a tremendous and various range of natural resources. The country is rich in natural resources comprised of the known mineral deposits of coal, gold, lead, tin, tungsten, manganese, zinc, and precious stones. The rich sedimentary soil along the Chao Phraya and other rivers constitutes another important resource. Furthermore, natural gas deposits were discovered offshore in the nineteen-seventies, reducing Thailand's reliance on imported petroleum (Royal Forest Department, 2019 and Department of Mineral Resourcesม 2019).

The plants and animals of Thailand's jungles and swamps, which are scattered through the coastal areas of Thailand, have extensive tracts of tropical trees, including mangrove, rattan, ironwood, sappanwood, ebony, and rosewood. The upland areas are also heavily wooded, with the most valuable species being teak, agalloch, and oak. In addition, a wide variety of tropical plants and fruit trees occur in Thailand, including orchid, gardenia, hibiscus, banana, mango, and coconut. Moreover, there are many species of animal that inhabit the jungles and forests. Elephants, which are widely used as beasts of burden, are abundant. Other large animals include the rhinoceros, tiger, 
International Journal of Innovation, Creativity and Change. www.ijicc.net

Volume 15, Issue 2, 2021

leopard, gaur, water buffalo, and gibbon. The Siamese cat is, as its name implies, indigenous to Thailand. The country has more than 50 species of snakes, including several poisonous varieties. Crocodiles are numerous, as are various species of fish and birds (Royal Forest Department, 2019 and Department of Mineral Resourcess 2019 and Department of National Park, Wildlife and Plant Conservation, 2019).

Thailand is one of the world's leading producers of rice, despite the fact that the yield per hectare is low. In the early nineteen-nineties, Thailand annually produced approximately 18.5 million metric tons of rice, which was up from approximately 11.3 million metric tons per year in the nineteen-sixties. The second most important crop in value is rubber, which is raised mainly upon plantations within the Malay Peninsula. In the early nineteen-nineties, approximately 1.4 million metric tonnes $(\mathrm{mT})$ of rubber was produced each year. Other important crops included cassava (21.1 million $\mathrm{mT}$ sugarcane (46.8 million $\mathrm{mT}$ ), maize (3.6 million $\mathrm{mT}$ ), pineapples (1.9 million $\mathrm{mT})$, coconuts (1.4 million $\mathrm{mT})$, and kenaf $(161,000 \mathrm{mT})$, which is a fibre used in making canvas. Furthermore, Livestock totaled approximately 6.8 million cattle, 4.8 million buffalo, 5.1 million pigs, and 153 million in poultry (Department of Agriculture, 2019 and Nicely 2018).

About 28 percent of the total land area of Thailand is forested. The most valuable forest product is hardwood. In the early nineteen-nineties, the annual timber harvest totaled about 37.6 million cubic meter (about 1.3 billion cubic feet), of which all but seven percent was burned for fuel. Thailand was a major exporter of teak until a ban on uncontrolled logging was instituted in 1989 following severe flooding, as a result of deforestation. In addition, fishing is rapidly growing in importance to the Thai economy. In the early nineteen-nineties, the annual catch included 3.1 million $\mathrm{mT}$ of prawns, fish, and shellfish, and the exports of ocean products, particularly prawns, accounted for approximately ten percent of export earnings.

Ecological damage includes environmental degradation, which is anything adversely affecting the ecological eminence or ecosystem balance. In the United Nations (UN) Climate Change News dated 15 March 2019, the UN published a comprehensive and rigorous assessment on the situation of the environment, warning that ecological damage to the planet is becoming so terrible that millions of lives will soon be at risk, and thus, it requires urgent action taken (United Nations, 2019). The report, which was produced by 250 scientists and experts from more than 70 countries, indicates that either humanity drastically scales up environmental protection, including climate protection or cities and regions, particularly in Asia, the Middle East, and Africa, could see millions of premature deaths by the mid-century. The report also highlights the fact that the world has the science, technology, and finance to move towards a more sustainable development pathway, although adequate support is still absent from the business and political leaders who are 
International Journal of Innovation, Creativity and Change. www.ijicc.net

Volume 15, Issue 2, 2021

holding on to obsolete production and development models (United Nations, 2019). Therefore, the ecological damage must consider the public attention to protect it (Thiengkamol, 2011e).

The term, 'civil liability', refers to the potential responsibility for the payment of damages or other court-enforcement in a lawsuit, as distinguished from criminal liability, which means it is open to punishment for a crime or refers to a person who is responsible to another person for damage or injury that they caused through bad acts or accidents. The persons found liable in a civil action are generally required to pay monetary damages to the compensate the party or parties they injured (Farlex, 2019).

Regarding 'criminal liability', it is the responsibility for any illegal behaviour that causes harm or damage to someone or something, particularly in the environmental aspect that includes any action with direct or indirect harm to people and the environment (Cambridge Dictionary, 2019).

'Administrative liability' is an area of law concerning the tortious liability of public bodies in the English law. The existence of private law tort applying to public bodies is a result of the Diceyan constitutional theory, which suggests that it would be unfair if a separate system of liability exists for government and officials. Therefore, a public body, which acts ultra vires, is liable in tort and is a cause of action that can be established just like any individual would be (Craig, 2008). An ultra vires action will not, per se, give rise to damages. Therefore, a claimant will have to fit into one of the recognised private law courses of action. These are areas in which a public body can incur private liability in tort (Harlow \& Rawlings, n.d.).

\section{Objectives}

1. To study environmental damage, natural resource damage, ecological damage, civil liability, criminal liability, administrative liability, and green behaviour levels.

2. To study the independent variables comprising environmental damage, natural resource damage, ecological damage, civil liability, criminal liability, and administrative liability affecting the dependent variable of the green behaviour of undergraduates.

\section{Methodology}

The research design was implemented across several steps, as follows: 
International Journal of Innovation, Creativity and Change. www.ijicc.net

Volume 15, Issue 2, 2021

\section{Population and Sample}

The population was comprised of 11,418 undergraduates of the Rajabhat Mahasarakham University in the second semester of the academic year of 2018. The multi-stage sampling technique was employed to collect the sample for 400 undergraduates (Schonlau, Fricker \& Elliott, 2002).

\section{Research Tool}

The research instrument was the questionnaire, and it was used for data collection purposes. The questionnaire consisted of six items of demographic characteristics and 42 questions using a fiverating scale across the subjects of environmental damage, natural resource damage, ecological damage, civil liability, criminal liability, administrative liability, and green behaviour levels. The content and structural validity were determined with the index of item-objective congruent (IOC) by five experts in the aspects of environmental law, social science, and social research methodology (Rovinelli \& Hambleton, 1977). Questionnaire's reliability was performed by collecting the sample group from 50 undergraduates of Mahasarakham University, Maha Sarakham Province, which was the similar characteristic of the sample group and they were not sample group. The reliability was determined with Cronbach's Alpha (Cronbach, 1951). The reliabilities of environmental damage, natural resource damage, ecological damage, civil liability, criminal liability, administrative liability, green behaviour, and the entire questionnaire were 0.85 , $0.89,92,0.93,0.87,0.91,0.88$, and 0.95 , respectively.

\section{Data Collection}

The questionnaire was used for the purpose of data collection from undergraduates of the Rajabhat Mahasarakham University in the second semester of the academic year of 2018.

\section{Statistical Analysis}

The descriptive statistics which were used included frequency, percentage, mean, and standard deviation. The rating for the explanation of the level of environmental damage, natural resource damage, ecological damage, civil liability, criminal liability, administrative liability, and green behaviour ranged from $0-1.50$ or 'very low' level, 1.51-2.50 or 'low' level, 2.51-3.50 or 'moderate' level, 3.51-4.50 or 'high' level, 4.51-5.00 as 'very high' level (Thiengkamol, 2016).

The inferential statistics that were used was the multiple regression analysis (Hair et al., 2010), which was performed by considering the confident interval at 0.05 , and 0.01 . 
International Journal of Innovation, Creativity and Change. www.ijicc.net

Volume 15, Issue 2, 2021

\section{Results}

\section{General Characteristics of Sample Group}

The sample group was comprised of 400 undergraduate students who studied at the Rajabhat Mahasarakham University during the academic year of 2018, while it consisted of 235 female (58.75 percent) and 165 male ( 42.25 percent). The majority of the sample size came from female students in Humanities and Social Science Faculty with 89 students (22.25 percent). The average age of the students was 19.13 years old. The majority of students were the eldest child in their family (198 students 48.5 percent), their father's occupation was as an agriculturist (298 students or 74.5 percent), and they had an average family income per month of 8,456.73 Bath.

\section{Results of Environmental Damage Level}

The results of the environmental damage level of the 400 undergraduates obtained a total mean score of 4.32 at the 'high' level. Meanwhile, considering each aspect, it was revealed that 'dumping waste into a canal is legal' at the 'high' level with a score of 4.56. It was followed by 'the Local Administrative Organisation legally has a duty in waste management' and 'every home needs to treat the household wastewater before drainage', obtaining scores of 4.39, and 4.29, respectively, as presented in Table 1.

Table 1: Environmental Damage Level

\begin{tabular}{llccc}
\hline Environmental Damage Level & $\overline{\mathrm{X}}$ & S.D. & Level \\
\hline 1. & Dumping waste to canal is legal. & 4.56 & 0.74 & High \\
2. $\quad \begin{array}{l}\text { Every home needs to treat the household wastewater before } \\
\text { drainage. }\end{array}$ & 4.29 & 0.68 & High \\
3. The airport causes noise pollution. & 4.25 & 0.67 & High \\
4. Feeding the river fish is illegal. & 4.16 & 0.69 & High \\
5. $\quad \begin{array}{l}\text { The Local Administrative Organisation has a legal duty in waste } \\
\quad \text { management. }\end{array}$ & 4.39 & 0.91 & High \\
6. Building roads creates waterway obstructions. & 4.19 & 0.77 & High \\
\hline Mean of Environmental Damage Level & $\mathbf{4 . 3 2}$ & $\mathbf{0 . 8 3}$ & $\mathbf{H i g h}$ \\
\hline
\end{tabular}


International Journal of Innovation, Creativity and Change. www.ijicc.net

Volume 15, Issue 2, 2021

\section{Results of Natural Resource Damage}

The results of the natural resource damage level of the 400 undergraduates obtained a total mean score at the 'high' level of 4.30. Meanwhile, considering each aspect, it was revealed that 'dam contrition vigorously destroys the natural resources' at the 'high' level with a result of 4.61. It was followed by 'rice cultivation must use pesticides but should not impact the environment' and 'cutting trees for shelter does damage the forest' at 4.39 , and 4.33 , respectively, as presented in Table 2.

Table 2: Natural Resource Damage

\begin{tabular}{llccc}
\hline Natural Resource Damage Level & $\overline{\mathrm{X}}$ & S.D. & Level \\
\hline $\begin{array}{l}\text { 1. } \\
\text { 2. }\end{array} \quad 4.33$ & 0.66 & High \\
$\quad \begin{array}{l}\text { Rice culting trees for shelter does damage the forest. } \\
\text { environment. }\end{array}$ & 4.39 & 0.71 & High \\
3. $\quad$ The sugar factory requires an air measurement system. & 4.27 & 0.67 & High \\
4. Burning the sugar cane field cause the air pollution. & 4.16 & 0.70 & High \\
5. The biomass power plant is the origin of air pollution. & 4.09 & 0.68 & High \\
6. Dam contrition vigorously destroys the natural resources. & 4.61 & 0.72 & High \\
\hline Mean of Natural Resource Damage & $\mathbf{4 . 3 0}$ & $\mathbf{0 . 7 3}$ & High
\end{tabular}

\section{Results of Ecological Damage Level}

The results of the ecological damage level of the 400 undergraduates obtained a total mean score at the 'high' level of 4.36. Meanwhile, considering each aspect, it was revealed that 'dam construction seriously destroys the ecological balance' at the 'high' level with 4.54. It was followed by 'factories legally drain hot water to the river or sea' and 'mining effects to water resources' at 4.45, and 4.39, respectively, as presented in Table 3.

Table 3: Ecological Damage Level

\begin{tabular}{llccc}
\hline Ecological Damage Level & $\overline{\mathrm{X}}$ & S.D. & Level \\
\hline 1. & Dam construction seriously destroys the ecological balance. & 4.54 & 0.65 & High \\
2. & Mining effects to water resources. & 4.39 & 0.73 & High \\
\hline
\end{tabular}


International Journal of Innovation, Creativity and Change. www.ijicc.net

Volume 15, Issue 2, 2021

\begin{tabular}{llrrr} 
3. & $\begin{array}{l}\text { Biological fertiliser should be used for maintaining the } \\
\text { ecosystem. }\end{array}$ & 4.28 & 0.70 & High \\
4. Oil spills destroy the marine ecosystem for numerous months. & 4.36 & 0.69 & High \\
5. Factories legally drain hot water to the river or sea. & 4.45 & 0.691 & High \\
6. Cutting trees in the forest damages the ecosystem. & 4.38 & 0.67 & High \\
\hline Mean of Air Pollution Knowledge Level & $\mathbf{4 . 3 6}$ & $\mathbf{0 . 7 1}$ & High \\
\hline
\end{tabular}

\section{Results of Civil Liability Level}

The results of the civil liability level of the 400 undergraduates had a total mean score at the 'high' level of 4.34. Meanwhile, considering each aspect, the 'polluter pays principle is justice for everyone' was at the 'high' level with 4.44. It was followed by 'to encroach the public space is legal' and 'up-stream farmers can restore the water for themselves as much as possible', obtaining results of 4.36, and 4.35, respectively, as presented in Table 4.

Table 4: Civil Liability Level

\begin{tabular}{|c|c|c|c|c|}
\hline \multicolumn{2}{|c|}{ Civil Liability Level } & \multirow{2}{*}{$\begin{array}{c}\bar{X} \\
4.35\end{array}$} & \multirow{2}{*}{$\begin{array}{l}\text { S.D. } \\
0.71\end{array}$} & \multirow{2}{*}{$\begin{array}{l}\text { Level } \\
\text { High }\end{array}$} \\
\hline 1. & $\begin{array}{l}\text { Up-stream farmers can restore the water for themselves as much } \\
\text { as possible. }\end{array}$ & & & \\
\hline 2. & $\begin{array}{l}\text { Filling the ground to a level higher than your neighbours to cause } \\
\text { flooding is illegal. }\end{array}$ & 4.29 & 0.69 & High \\
\hline 3. & The polluter pays principle is justice for everyone. & 4.44 & 0.67 & High \\
\hline 4. & To encroach the public space is legal. & 4.36 & 0.70 & High \\
\hline 5. & $\begin{array}{l}\text { The biomass power plant must pay for people who get sick from } \\
\text { the dust elimination of the plant. }\end{array}$ & 4.29 & 0.68 & High \\
\hline 6. & It is a civil liability if people dump waste to a waterway. & 4.12 & 0.67 & High \\
\hline \multicolumn{2}{|c|}{ Mean of Civil Liability Level } & 4.34 & 0.70 & High \\
\hline
\end{tabular}

\section{Results of Criminal Liability Level}

The results of the criminal liability level of the 400 undergraduates obtained a total mean score at the 'high' level of 4.37. Meanwhile, considering each aspect, the 'slaughterhouse must control water, air, and odour pollutions to follow criminal liability' was at the 'high' level with 4.52. It 
International Journal of Innovation, Creativity and Change. www.ijicc.net

Volume 15, Issue 2, 2021

was followed by 'dumping waste to a river is a criminal liability' and 'pesticide use for cultivation is a criminal liability', obtaining a result of 4.35, and 4.29, respectively, as presented in Table 5.

Table 5: Criminal Liability Level

\begin{tabular}{llccc}
\hline Criminal Liability Level & $\overline{\mathrm{X}}$ & S.D. & Level \\
\hline 1. & Dumping waste to a river is a criminal liability. & 4.35 & 0.67 & High \\
2. $\quad$ Pesticide use for cultivation is a criminal liability. & 4.29 & 0.72 & High \\
3. $\quad \begin{array}{l}\text { The slaughterhouse must control water, air, and odour pollutions } \\
\text { to follow criminal liability. }\end{array}$ & 4.52 & 0.73 & High \\
4. It is a criminal liability for pig farms to impact people. & 4.16 & 0.67 & High \\
5. $\quad \begin{array}{l}\text { The quarrying plant causes air pollution and makes people in the } \\
\quad \text { surrounding area sick. The activity is a criminal liability. }\end{array}$ & 4.09 & 0.71 & High \\
6. Resort operations in a conservation forest are a criminal liability. & 4.23 & 0.67 & High \\
\hline Mean of Criminal Liability Level & $\mathbf{4 . 3 7}$ & $\mathbf{0 . 7 0}$ & High \\
\hline
\end{tabular}

\section{Results of Administrative Liability Level}

The results of the administrative liability level of the 400 undergraduates had a total mean score at the 'high' level of 4.26. Meanwhile, considering each aspect, People can sue the factories that create pollution was at the 'high' level with 4.54. It was followed by 'the Local Administrative Organisation has no duty to mitigate the local factory' and 'people can sue the Government for making roads through a forest', which obtained scores of 4.21, and 4.18, respectively, as presented in Table 6.

Table 6: Administrative Liability Level

\begin{tabular}{|c|c|c|c|c|}
\hline \multicolumn{2}{|c|}{ Administrative Liability Level } & \multirow{2}{*}{$\begin{array}{r}\bar{X} \\
4.54\end{array}$} & \multirow{2}{*}{$\begin{array}{l}\text { S.D. } \\
0.72\end{array}$} & \multirow{2}{*}{$\begin{array}{c}\text { Leve } \\
\text { High }\end{array}$} \\
\hline 1. & People can sue the factories that create pollution. & & & \\
\hline 2. & $\begin{array}{l}\text { People can sue the Government for making roads through a } \\
\text { forest. }\end{array}$ & 4.18 & 0.66 & High \\
\hline 3 & $\begin{array}{l}\text { Cable car building causes pollution and people can sue the } \\
\text { Government. }\end{array}$ & 3.99 & 0.77 & High \\
\hline
\end{tabular}


International Journal of Innovation, Creativity and Change. www.ijicc.net

Volume 15, Issue 2, 2021

\begin{tabular}{|c|c|c|c|c|}
\hline t. & $\begin{array}{l}\text { People can sue the Government if an allowance to build public } \\
\text { transport occurs without the agreement of the people. }\end{array}$ & 4.10 & 0.70 & High \\
\hline 5 & $\begin{array}{l}\text { Rapid train construction can cause pollution and people can sue } \\
\text { the Government. }\end{array}$ & 4.15 & 0.68 & High \\
\hline & $\begin{array}{l}\text { The Local Administrative Organisation has no duty to mitigate } \\
\text { the local factories. }\end{array}$ & 4.21 & 0.67 & High \\
\hline \multicolumn{2}{|r|}{ In of Administrative Liability Level } & 4.2 & 0.71 & Hig \\
\hline
\end{tabular}

\section{Results of Green Behaviour Level}

The findings revealed that the green behaviour level of the 400 undergraduates from a holistic view was at the 'high' level with a result of 4.12. Meanwhile, considering each aspect, 'consuming the local food and fruit that exists locally is a green behaviour' was at the 'high' level with a score of 4.26. It was followed by 'refill products are favoured for the conservation of the environment' and 'solar energy is used for drying cloths', obtaining scores of 4.16, and 4.12, respectively, as presented in Table 7.

Table 7: Result of Green Behaviour Level

\begin{tabular}{|c|c|c|c|c|}
\hline \multicolumn{2}{|c|}{ Green Behaviour Level } & \multirow{2}{*}{$\begin{array}{r}\bar{X} \\
4.09\end{array}$} & \multirow{2}{*}{$\begin{array}{c}\text { S.D. } \\
0.70\end{array}$} & \multirow{2}{*}{$\begin{array}{l}\text { Level } \\
\text { High }\end{array}$} \\
\hline 1. & $\begin{array}{l}\text { Consuming seasonal fruit is a behaviour of conserving the } \\
\text { environment. }\end{array}$ & & & \\
\hline 2. & $\begin{array}{l}\text { Consuming the local food and fruit that exists locally is a } \\
\text { green behaviour. }\end{array}$ & 4.26 & 0.68 & High \\
\hline 3. & Solar energy is used for drying cloths. & 4.12 & 0.72 & High \\
\hline 4. & To save energy, the alternative energy is used. & 4.09 & 0.69 & High \\
\hline 5. & Plastic product is disposed of by burning it. & 3.99 & 0.67 & High \\
\hline 6. & $\begin{array}{l}\text { Refill products are favoured for the conservation of the } \\
\text { environment. }\end{array}$ & 4.16 & 0.65 & High \\
\hline 7. & Reusing plastic bags is a green behaviour. & 3.96 & 0.78 & High \\
\hline 8. & The practice of recycling is a green behaviour. & 3.86 & 0.69 & High \\
\hline \multicolumn{2}{|r|}{ Mean of Green Behaviour Level } & 4.12 & 0.72 & High \\
\hline
\end{tabular}


International Journal of Innovation, Creativity and Change. www.ijicc.net

Volume 15, Issue 2, 2021

\section{Results of the Independent Variables Affecting the Dependent Variable of the Undergraduates}

The relationship between the independent variables - which comprise environmental damage, natural resource damage, ecological damage, civil liability, criminal liability, and administrative liability - affecting the dependent variable of the green behaviour of the undergraduates, is presented in Tables 8 , and 9.

Table 8: Result Analysis Prediction Power of Independent Variables Affecting the Dependent Variable

\begin{tabular}{ccccc}
\hline Model & $\mathrm{R}$ & R Square & Adjusted R Square & $\begin{array}{c}\text { Std. Error of the } \\
\text { Estimate }\end{array}$ \\
\hline 1 & $0.782^{\mathrm{a}}$ & 0.658 & 0.656 & 0.368
\end{tabular}

a. Predictors: constant, environmental damage, natural resource damage, ecological damage, civil liability, criminal liability, and administrative liability affecting green behaviour

b. Dependent Variable: green behaviour

Table 9: Multiple Linear Regression Analysis between Result Analysis Prediction Power of Independent Variables Affecting the Dependent Variable

\begin{tabular}{llccccc}
\hline & Model & Sum of Squares & df & Mean Square & F & Sig. \\
\hline 1 & Regression & 45.659 & 6 & 7.610 & 8.397 & $0.000^{\mathrm{a}}$ \\
& Residual & 341.655 & 377 & 0.906 & & \\
& Total & 387.314 & 383 & & & \\
\hline
\end{tabular}

a. Predictors: constant, environmental damage, natural resource damage, ecological damage, civil liability, criminal liability, and administrative liability affecting green behaviour

b. Dependent Variable: green behaviour

As shown in Tables 8 and 9, when the multiple linear regression was analysed between the independent variables affecting the dependent variable, the regression coefficient was equal to 0.782 (78.2 percent) and the coefficient of R Square was 0.658 (65.8 percent) at the statistically significant level of 0.01 . After it was adjusted, the coefficient of R Square with the power of prediction was 0.656 (65.6 percent). 
International Journal of Innovation, Creativity and Change. www.ijicc.net

Volume 15, Issue 2, 2021

Results of the Analysis of the Prediction Power of the Independent Variables Affecting the Dependent Variable

The relationship between the result of the analysis of prediction power of the independent variables affecting the dependent variables is illustrated in Table 10.

Table 10: Relationship between the Result of the Analysis of Prediction Power of the Independent Variables Affecting the Dependent Variable

\begin{tabular}{|c|c|c|c|c|c|c|}
\hline & \multirow[t]{2}{*}{ Model } & \multicolumn{2}{|c|}{$\begin{array}{c}\text { Unstandardised } \\
\text { Coefficients }\end{array}$} & \multirow{2}{*}{$\begin{array}{c}\text { Standardised } \\
\text { Coefficients } \\
\text { Beta }\end{array}$} & \multirow[t]{2}{*}{$\mathrm{t}$} & \multirow[t]{2}{*}{ Sig. } \\
\hline & & B & Std. Error & & & \\
\hline \multirow[t]{7}{*}{1} & Constant & 0.136 & 0.148 & - & 2.486 & $0.013 *$ \\
\hline & $\begin{array}{l}\text { Environmental } \\
\text { Damage }\end{array}$ & 0.152 & 0.051 & 0.165 & 2.963 & $0.00 *$ \\
\hline & $\begin{array}{l}\text { Natural } \\
\text { Resource } \\
\text { Damage }\end{array}$ & 0.098 & 0.063 & 0.109 & 1.562 & 0.119 \\
\hline & $\begin{array}{l}\text { Ecological } \\
\text { Damage }\end{array}$ & 0.071 & 0.047 & 0.081 & 1.514 & 0.131 \\
\hline & Civil liability & 0.145 & 0.046 & 0.672 & 17.502 & $0.00 * *$ \\
\hline & $\begin{array}{l}\text { Criminal } \\
\text { Lability }\end{array}$ & 0.236 & 0.034 & 0.398 & 10.845 & $0.00 * *$ \\
\hline & $\begin{array}{l}\text { Administrative } \\
\text { Lability }\end{array}$ & 0.170 & 0.046 & 0.672 & 17.502 & $0.00 * *$ \\
\hline
\end{tabular}

a. Predictors: constant, environmental damage, natural resource damage, ecological damage, civil liability, criminal liability, and administrative liability affecting green behaviour

b. Dependent Variable: green behaviour

From the findings of Table 10, which showed the multiple linear regression equation, it was revealed that the result of the analysis of the prediction power of environmental damage, civil liability, criminal liability, and administrative liability affecting the dependent variable of green behaviour were statistically significant at the level of 0.01 . The natural resource damage, and ecological damage were not statistically significant at the level of 0.05 . 
International Journal of Innovation, Creativity and Change. www.ijicc.net

Volume 15, Issue 2, 2021

The equation one can be written as follows:

$$
y=a+b 1 \times 1+b 2 \times 2+b 3 \times 3+b 4 \times 4+b 5 \times 5+b 6 \times 6
$$

When

$$
\begin{aligned}
& \text { y }=\text { Green Behaviour as Dependent Variable } \\
& \text { a }=\text { constant value } \\
& \text { b1 }=\text { Coefficient relation of Environmental Damage } \\
& \text { x1 }=\text { Environmental Damage as Independent Variable } \\
& \text { b2 }=\text { Coefficient relation of Natural Resource Damage } \\
& \text { x2 }=\text { Natural Resource Damage } \\
& \text { b3 }=\text { Coefficient relation of Ecological Damage } \\
& \text { x3 }=\text { Ecological Damage as Independent Variable } \\
& \text { b4 }=\text { Coefficient relation of Natural Resource Damage } \\
& \text { x4 }=\text { Civil Liability } \\
& \text { b5 }=\text { Coefficient relation of Criminal Liability } \\
& \text { x5 }=\text { Criminal Liability as Independent Variable } \\
& \text { b6 }=\text { Coefficient relation of Administrative Liability } \\
& \text { x6 }=\text { Administrative Liability }
\end{aligned}
$$

The prediction equation shows the relationship between the independent variables of environmental damage, natural resource damage, ecological damage, civil liability, criminal liability, and administrative liability affecting the dependent variable of the green behaviour of the undergraduate students.

It can be explained that criminal liability had the most effect towards people's air quality maintenance behaviour at a rate of 23.6 percent and was statistically significant at the level of 0.01 . It was followed by administrative liability with 17.00 percent, which was statistically significant at the level of 0.01 , as per the following equation two.

$$
\mathrm{y}=0.136+0.152 \times 1+0.098 \times 2+0.071 \times 3+0.145 \times 4+0.236 \times 5+0.170 \times 6 .
$$

\section{Discussions}

The findings illustrate that the independent variable of environmental damage was measured by the six items. It was revealed that the item of 'dumping waste into a canal is legal' was shown at the 'high' level with a result of 4.56. This might indicate that people are aware and understand that 
dumping waste is a serious action that destroys the environmental quality. It is congruent to the study of Lhaophet et al. (2016), entitled the "Environmental Education Factor Affecting Waste Management Behavior of Villager", that environmental knowledge affects waste management behaviours. Moreover, the results of a study on natural resource damage showed that dam construction vigorously destroys the natural resources, with a score of 4.61 at the 'high' level. This was also pertinent to the research of Wongsompong et al. (2016), who conducted a study entitled, "Model of Factors Affecting Forest Conservation", which noted that people will not agree to construct a dam because they want to protect the forest.

However, the results of ecological damage showed that dam construction seriously destroys the ecological balance at the 'high' level with a score of 4.54. This is in line with the study of Sangkaew et al. (2016), "Model of Factors Affecting Environmental Conservation Behavior of Junior High School Student", which revealed that the ecological and environmental knowledge are directly and indirectly related to environmental conservation behaviours. Consequently, the results of civil liability showed that 'the polluter pays principle is justice for everyone' was at the 'high' level with a score of 4.44. People recognised that civil liability was important issues in accordance with the 'polluter pays principle' which stated that the polluters much pay accordance with the damage done to environment.

Nevertheless, the results of criminal liability illustrated that 'the slaughterhouse must control water, air, and odour pollutions to follow criminal liability' was at the 'high' level with a score of 4.52. This is congruent to the study of Srikaewtoom et al. (2015), entitled "Environmental Conservation Model for Swine Farm", which noted that swine farming causes numerous facets for environmental quality, whether it is water quality, air quality or soil quality, including the bad odours that annoy the people's quality of life.

Additionally, the results of administrative liability indicated that 'the Local Administrative Organisation has no duty to mitigate the local factories' was at the 'high' level with a score of 4.54. It is congruent to the study of Borvornsakulcharoen et al. (2015) on the "Model of Environmental Law Knowledge for Undergraduate", which revealed that administrative liability predicts the environmental law knowledge with a score of 33.00, and environmental law knowledge directly and indirectly is related to environmental conservation behaviours. Finally, the research result indicated that criminal liability affecting or predicting the green behaviour was at a rate of 23.6 percent, being the highest effect when compared to others, such as environmental damage, ecological damage, civil liability, and administrative liability. It results may explain that the undergraduates or people in general are frightened of being punished by the criminal law because of the common notion of being scared to be kept as a prisoner. 
International Journal of Innovation, Creativity and Change. www.ijicc.net

Volume 15, Issue 2, 2021

\section{REFERENCES}

Borvornsakulcharoen, D. Thiengkamol, N., Thiengkamol Khoowaranyoo, T. (2015). Model of Environmental Law Knowledge for Undergraduate. Journal of Industrial Education, 14(3), 734-740.

Cambridge Dictionar. (2019). Criminal Liability. Retrieve from https://dictionary.cambridge.org/dictionary/english/criminal-liability

Craig, P. (2008). Administrative Law (6th ed.). London; Sweet \& Maxwell.

Cronbach, J. (1951). Coefficient alpha and the internal structure of tests. Psychometrika, 16 (3), 297-334.

Department of Agriculture. (2019). Agricultural Products. Retrieve from: http://www.doa.go.th/en/?page id=22

Department of Environmental Conservation. (2019). Natural Resource Damages (NRD). Retrieved from: https://www.dec.ny.gov/regulations/2411.html

Department of Mineral Resources. (2019). ANNUALREPORT2017. Retrieved from: http://www.dmr.go.th/download/annual_report_\%202560.pdf

Department of National Park, Wildlife and Plant Conservation. (2019). National Park. Retrieved from: http://www.dnp.go.th/index_eng.asp

Farlex. (2019). Civil Liability. Retrieved from: https://www.thefreedictionary.com/civil+liability

Hair, J., Black, Jr, W., Babin, B. and Anderson, R. (2010). Multivariate Data Analysis. 7th ed. New Jersey: Prentice Hall.

Harlow, C.; Rawlings, R. Law and Administration (2nd ed.). Cambridge University Press. p. 620. ISBN 978-0521701792.

Lhaophet, N. Thiengkamol, N., Thiengkamol, C. (2016). Environmental Education Factor Affecting Waste Management Behavior of Villager. EAU Heritage Journal: Science and Technology. 10 (1), 145-156.

LSE. Z2018). What is the polluter pays principle? Retrieved from: http://www.nesdb.gohttp://www.Ise.ac.uk/GranthamInstitute/faqs/what-is-the-polluter-paysprinciple/.th/Default.aspx?tabid=90

Nicely, R. (2018). Thailand Poultry and Products Annual. Retrieved from: https://gain.fas.usda.gov/Recent\%20GAIN\%20Publications/Poultry\%20and\%20Products\% 20Annual_Bangkok_Thailand_9-6-2018.pdf

Richardson, B.J. and S. Wood (eds). (2006). Environmental Law for Sustainability (Hart Publishing: Oxford.

Rovinelli, R. J. and Hambleton, R. K. (1977). On the use of Content Specialists in the Assessment of Criterion-referenced Test item Validity. Dutch Journal of Educational Research, 2, 49-60. 
International Journal of Innovation, Creativity and Change. www.ijicc.net

Volume 15, Issue 2, 2021

Royal Forestry Department. (2019). Natural Resources. Retrieved from: https://www.bangkokpost.com/business/companies\%20in\%20thailand/13130/royal-forestdepartment

Sangkaew, M. Thiengkamol, N., Thiengkamol C. (2016). Model of Factors Affecting Environmental Conservation Behavior of Junior High School Student. Journal of Kasem Bundit, 17(2):140-160.

Schonlau, M., Fricker, R., \& Elliott, M. (2002). BACKGROUND ON THE SURVEY PROCESS. In Conducting Research Surveys via E-mail and the Web (pp. 5-18). Santa Monica, CA; Arlington, VA; Pittsburgh, PA: RAND Corporation. Retrieved from http://www.jstor.org/stable/10.7249/mr1480rc.10

Srikaewtoom, P., Prasertsri, N., \& Thiengkamol Khoowaranyoo, T. (2015). Environmental Conservation Model for Swine Farm. EAU Heritage Journal, 9(2):233-245.

Thiengkamol, N. (2011e). Environment and Development Book. (4th ed.).Bangkok: Chulalongkorn University Press.

Thiengkamol, N. (2016). Theory Development with LISREL Research. Bangkok: CU Printing House. United Nations. (2019). Ecological Damage Putting Millions of Lives at Risk. Retrieved from: https://unfccc.int/news/un-ecological-damage-putting-millions-of-lives-atrisk.

Wongsompong, T., Thiengkamol, N., Thiengkamol, C. (2016). Model of Factors Affecting Forest Conservation. EAU Heritage Journal: Science and Technology.10 (1), 121-132.

Yamane, (1973) Statistics: An Introductory Analysis.3rd ed. Tokyo: Harper International Edition. 